\title{
International News / Nouvelles internationales
}

\section{What Is 'Adaptive Co-Management'?}

Given the trend in many countries of devolving management of community forests to people at the local level, new methods of decision-making are emerging to enable different - often competing - interest groups to reach mutually acceptable agreements. An approach we call "adaptive co-management" (ACM) should be a highly effective strategy for achieving this. In line with overlapping goals of its local livelihoods and its criteria and indicators programmes, CIFOR will investigate the use of ACM to promote sustainable forest management.

$\mathrm{ACM}$ is rooted in collaborative management techniques that are increasingly being applied today in various fields of natural resource management. This more inclusive approach is gaining favour out of a growing consensus that without some basic agreement among all the affected parties (stakeholders) about how and for what purpose the resource is being maintained, sustainability cannot be achieved and degradation will continue.

At the same time, ACM draws on models of yet another decision-making process that is gradually being adopted in natural resource planning: adaptive management. Proponents see it as a way to address the complexity and uncertainty inherent in natural resource management. The approach is iterative; it provides for regular analysis of progress toward established objectives, and calls for adjustment where necessary in response to changing circumstances. (This might include, for example, changes in stakeholder's perceptions of a situation or changes in environmental conditions.) Thus, adaptive management is highly compatible with efforts by CIFOR and other institutions to develop criteria and indicators that can be used to guide movement toward sustainable forest management.

Apart from these well-documented methodologies, ACM also includes a recognition of the potentially valuable lessons that may be learned from the traditional - and often not formalised adaptive and collaborative ways in which villagers have managed forest resources for centuries.
There is no single solution for achieving sustainable community management of forests, as needs and priorities differ from setting to setting. ACM is flexible enough to address these differences and to allow individually appropriate responses. CIFOR's new research initiative will investigate a variety of tools that may be useful in applying ACM, such as stakeholder planning techniques, conflict resolution exercises, and criteria and indicators for monitoring management. We also view scenario analysis as a tool that holds considerable promise because of its ability to enable people to consider hypothetical possibilities that challenge their prevailing assumptions.

Whatever techniques are employed, a key aspect of ACM is that it should help local communities develop shared perceptions about how common area forests should look as they continue providing for a variety of needs. This foundation may serve as a vehicle for joint negotiation about the course of future management.

The ACM Project CIFOR News

\section{CIFOR to Assist in Surveys of Fire Impacts}

In November, Dr. Reidar Persson, CIFOR's Assistant Director General, met with U.S. officials in Salt Lake City, Utah, and Washington, DC, to discuss plans for a remote-sensing project on the fires that devastated large areas of Indonesia a year ago. The project is being financed by the U.S. Forest Service and the U.S. Agency for International Development.

Fred Stolle of the International Centre for Research in Agroforestry (ICRAF) also attended the sessions. ICRAF, with its Southeast Asia Regional Office in Bogor, has been working closely with CIFOR and other institutions on a number of initiatives related to the 1997-98 fires and others that have occurred throughout the region in recent decades. [See report in CIFOR News No. 20, pg. 8.]

The fires last year, which burnt large areas in Sumatra and Kalimantan (Borneo), were widely considered to be one of the worst on record, causing damage estimated in billions of dollars. Nonetheless, it is not known exactly how large an area was destroyed, which has prompted calls for major surveys to determine the exact number of hectares burnt.

According to Dr. Persson, CIFOR and ICRAF believe the cost of completing such a comprehensive assessment would be exorbitant, and have argued that the limited funds available about US $\$ 600000$ so far - should be used instead to acquire the kind of data needed to analyse the causes and impacts of the fires. A combination of remote sensing and local social studies can give a better understanding of the causes, making it possible to identify meaningful actions, they say.

Two preliminary sites have been proposed for detailed studies: Lampung (Sumatra) and East Kalimantan. AVHRR, Landsat and Spot data for these sites will be obtained. The U.S. Forest Service will coordinate the acquisition of remotesensing data, while CIFOR and ICRAF will do "ground-truthing" (field checks), decide land use changes and undertake the social studies.

Dr. Persson said CIFOR and ICRAF are working with U.S. officials to complete a formal proposal on the project, which should get underway early in 1999. CIFOR and ICRAF are also working to secure additional funds. This would make it possible to widen the remote-sensing work (for better area estimates, for example) and to investigate more deeply the underlying causes and learn more about what can be done to reduce fires in future dry years.

CIFOR News 


\section{International Community Forestry Movement Launched}

A new international community forestry movement was launched in March 1999 with the release of an International Statement on community forestry supported by over eighty individuals from eighteen countries.

The "Saanich Statement" was developed by top community forestry experts from around the Asia-Pacific region during an international meeting held last October on the Saanich Peninsula, British Columbia, just north of Victoria. The Statement lists key principles necessary to sustain forests, communities and cultures around the world.

"This declaration sets out the needed actions and policy reforms at the local, national and international levels if we are to sustain the world's forests and the people that depend on them," says Cheri Burda, of the University of Victoria's EcoResearch Chair of Environmental Law and Policy, who has coordinated the project.

Organizations around the world are being invited to sign onto the Statement and join the international network and movement. "This new network will work to support community forestry locally and globally in a similar way to the Forest Stewardship Council's support for ecologically rigorous forest certification," says Dr. Michael M'Gonigle Professor and EcoResearch Chair of Environmental Law and Policy at University of Victoria, which hosted the meeting. "As the participants agreed, the network will act as an advocacy organization to support and promote policy change for community forestry here and around the world."

While many community forestry networks currently exist around the world, they remain focused in the South, particularly Asia and Latin America. "There is a lot to be learnt from the tropical forest regions where many communities have successfully struggled for their right to manage forests to be recognized by regional and national authorities," says Patrick Anderson, Forest Campaigner for Greenpeace International. "This new network will provide an opportunity for Canada, where community forestry is in its infancy, to learn from these models."

In regions such as Papua New Guinea, the international network is needed to support local initiatives. "There are many
Community Forestry activities in PNG which make it very difficult for the State to control and suppress traditional land rights," says Sasa Zibe Kokino from Village Development Trust. "Through the network we will be able to gain support and awareness for these initiatives on an international level."

"This International Statement and the Network are two very important international strategies that with time will promote and achieve objectives for sustainable development within forest communities," says Lujan Alvarez, Professor and Researcher at the University of Autonoma de Chihuahua in Mexico. "The Network and The Saanich Statement bring together common paths to support actions for sustainable forest communities at international, national and local levels."

A new Network Web Site invites organizations to participate in the network by signing onto the Statement. The web site highlights community forestry solutions from around the world that are ecologically and socially sustainable.

"Some community forestry models exist here in $\mathrm{BC}$ and elsewhere that are oriented towards short-term revenue generation or simply emulate the industrial model," says Rami Rothkop director of Harrop-Procter Watershed Protection Society, a community forestry initiative in British Columbia. "Community forestry, rather, should be a vehicle for more ecologically sustainable forestry and healthy, diverse, valueadded local economies. It is the directive of the network to link and promote these types of alternatives."

As well as linking North and South, the network links many sectors including NGOs, academics, policy makers, foresters, government, consultants, community groups and aboriginal groups.

"With the recent Supreme Court of Canada ruling, BC Aboriginal communities have a unique opportunity to legally require ecologically sound forest management principles in modern treaties," says Russell Collier a Land and Resource Planner with the Gitxsan Nation. "Through the network we will be able to advocate policy change on an international level as well as share our lessons, experience and expertise."

WEB SITE: forestsandcommunities.org

\begin{abstract}
Submission of News Items
Submissions of information for publication in The Forestry Chronicle are due the first working day of the month preceding each issue (e.g., September/October issue -2 August. The publisher cannot guarantee the return of photos and manuscripts.
\end{abstract}

\begin{tabular}{|ll|}
\hline & $\begin{array}{l}\text { The Forestry Chronicle } \\
\text { Editorial Schedule 1999 }\end{array}$ \\
January/February & $\begin{array}{l}\text { Forest Economics and Forest Issues } \\
\text { Open Forum }\end{array}$ \\
May/June & $\begin{array}{l}\text { Long Term Silviculture Research Sites } \\
\text { (Editorial: Ron McDonald, CEO-COFI) } \\
\text { July/August }\end{array}$ \\
$\begin{array}{l}\text { Open Forum } \\
\text { September/October }\end{array}$ & $\begin{array}{l}\text { Forest Communities - Sustainability } \\
\text { November/December }\end{array}$ \\
\hline
\end{tabular}


The federal government is being sued again under NAFTA by yet another American company, this time because of the softwood lumber quota agreement between Canada and the United States.

Pope \& Talbot Inc., a forest products company based in Portland, Ore., is claiming \$30-million (US) in damages under the North American free-trade agreement's investor-state mechanism, the Department of Foreign Affairs and International Trade said yesterday.

The company says the softwood lumber agreement is unfair and discriminates against the company because it is only applied in four provinces but not others.

Under pressure from US lumber producers, Canada agreed to limit its softwood exports to the United States in return for trade peace. The five-year agreement ends in 2002.

Pope \& Talbot, although it's an American company, finds itself limited by the agreement because it exports lumber from Canada to the United States.

The company operates in British Columbia, where the softwood lumber quota is applied. It does not receive the same treatment that it would if it operated in a province where the quota agreement does not apply, the company argues.

That means if Pope \& Talbot exports lumber above the quota line, it has to pay a levy that forest companies in some other provinces don't have to pay.

"No levy is imposed on lumber companies in the provinces of Saskatchewan, Manitoba, New Brunswick, Prince Edward Island, Nova Scotia and Newfoundland and in the Canadian territories," the company says in its notice of intent to sue Ottawa.

Pope \& Talbot also argues that Canada is breaching its obligations to treat all foreign investors alike.

To compensate for its lost business which the company argues is the same thing as expropriation - Pope \& Talbot wants \$30-million.

The notice was filed in late December. The company and the government have until March 24 to work out a solution, but the case will proceed to binding arbitration if no compromise is found.

Trade officials would not comment on the merits of the case. Instead, they stressed the fact that they publicly released the details of the case rather than try to keep them secret, as has been done in previous cases.

"The reason we're making this public is because it's in keeping with [Trade Minister Sergio] Marchi's policy to be transparent," departmental spokesman André Leblanc said yesterday.

This is the fourth time in the past year that an American company has used NAFTA to sue Ottawa for compensation. The companies have all claimed that Canadian laws have robbed them unfairly of market opportunities in Canada.

The storm of NAFTA lawsuits was set off last summer after Ottawa settled with Virginia-based Ethyl Corp. As Ethyl's lawsuit advanced through the bureaucratic hoops, Ottawa brought the case to an end by paying the American company about \$19-million (Canadian) and agreeing to rescind a ban on imports of Ethyl's MMT product, a manganese-based gas additive.

Since then, companies have lined up to use the investment chapter of NAFTA to sue Ottawa. S.D. Myers Inc. of Ohio is claiming \$20-million (U.S.) in damages for a temporary federal ban on the export of polychlorinated biphenyls in 1995 and 1996. And Sun Belt Water Inc. of California is claiming \$220-million in damages stemming from a ban on water exports in British Columbia.

At least one Canadian company has jumped into the NAFTA fray too. Funeral giant Loewen Group Inc. is suing Washington for losses sustained in a Mississippi court.

The rash of lawsuits, and the secrecy surrounding the arbitration process, has prompted Mr. Marchi to ask the NAFTA partners to add clarifications to the NAFTA investment chapter. He says he wants to make the NAFTA process more public, and he wants to make it clear that NAFTA shouldn't be used by companies to strike down reasonable environmental regulations.

Globe \& Mail

\section{Invest In The Future Keep Your Woodlot In Full Production}

$\begin{array}{lll}\text { Reforest } & \text { - old fields } & \text { - poorly regenerating areas } \\ & \text { - clearings } & \text { - under hardwood stands } \\ & \text { - clearcuts } & \end{array}$

For the past 20 years Fraser Papers Tree Nursery has produced over 90 million seedlings for it's own use, for other industries and for many woodlot owners in Maine and New Brunswick.

Fraser Papers has the high quality seedlings (grown from improved seeds) that you need for your reforestation purposes. Species available: black spruce, white spruce, Norway spruce, red pine, white pine and otherspecies.

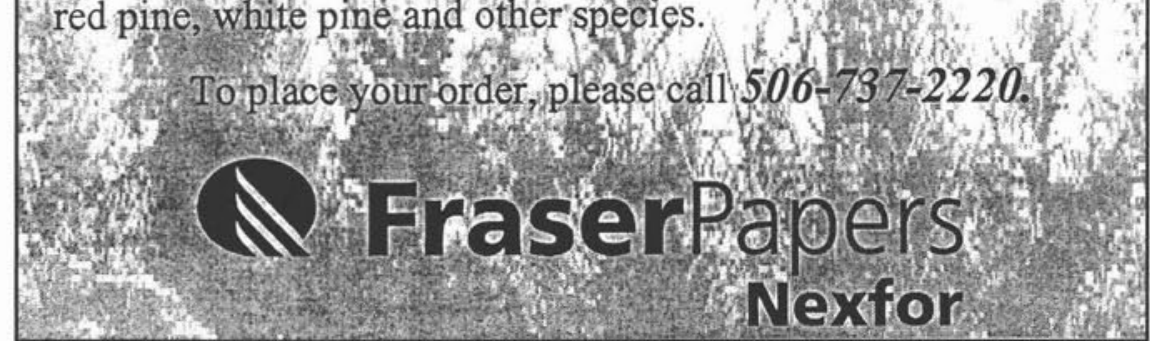




\section{Austria and CIFORs "C\&I"}

Three years after CIFOR conducted field tests in Austria as part of efforts to develop "criteria and indicators" (C\&I) for sustainable forest management, the government of Austria has drawn heavily on the results in a report that lays out guidelines for creating a national timber certification programme.

The report, prepared by the Austrian Federal Environment Office, is a "handbook" for forest managers and owners who wish to apply for a quality mark signifying that their timber and related products come from forests that are sustainably operated. It describes the standards required in certification programmes and how proof of compliance is carried out.

Austria has been laying the groundwork for adoption of a timber certification programme since it was mandated by a federal law in 1993. In late 1995, environmental officials in Austria carried out tests - based on CIFOR methodology - in several different forest areas to determine the effectiveness of various C\&I for assessing sustainability in several areas. The results were winnowed down to about 140 criteria and indicators that the testers deemed relevant for certification standards.

CIFOR News

\section{Workshop on Forest Convention}

Under the presidency of Austria an informal EU Workshop on "Elements of a Forest Convention" took place from 16 to 17 October 1998 in Vienna. Professor Peter Glück was invited to give a summary of the EFI study prepared for the European Commission two years ago on "Options for Strengthening the International Legal Regime for Forests." Although an agreement was achieved in the second session of the Intergovernmental Forum on Forests (IFF) this summer in Geneva that international co-operation is necessary to ensure conservation and sustainable development of forests, the positions of the participating countries differ with respect to the area of desired co-operation as well as the form-legally binding or non-legally binding instrument on forests. The 35 delegates from the EU Member States tried to clarify the EU position on this issue. The Workshop revealed

\section{Millennium Partnership for Safeguarding Europe's Nature}

Participants of the European Seminar "A Future for Europe's Nature and Biodiversity" made a plea for a millenium partnership to counteract the rapid decline of European nature. It was organised by the European Centre for Nature Conservation in Tilburg, The Netherlands to celebrate its fifth anniversary.

Despite all the efforts by the national and international communities, it was recognized that Europe's nature is still disappearing at an alarming rate. This is shown in the European ecological assessment "Facts and Figures," presented by ECNC at the seminar. The participants addressed the main issues of decline in Europe's nature, being insufficient political profile of Europe's nature conservation, weak implementation of nature conservation instruments and insufficient integration of ecology and economy.

Various scenarios for Europe's nature in the 21 st century were discussed, and new visions for the future of Europe's nature in the 21st century were developed. An increasing threat to Europe's nature is climate change, which will result in a shift or complete extinction of vegetation zones and coastlines, as stated by Prof. Frank Berendse of the Wageningen University (NL). Representatives from East and Central European countries stressed the need for international concerted action and partnership to safeguard their abundant nature as a basis for a sustainable economice development. Mrs Geke Faber, The Dutch State Secretary for Agriculture, Nature Management and Fisheries urged for a political priority for Europe's nature conservation, greater efficiency and streamlining the efforts for Europe's nature. Mr. Rob Wolters, the Executive Director of ECNC, said that the EU accession process will predominantly determine the future of nature in Central and Eastern Europe: "If clear steps are made towards an integrated EU rural policy, nature may benefit considerably. If not, the opposite may be true." $\mathrm{He}$ stresses the enormous economic value of nature in this region for sectors such as agriculture, forestry and tourism.

The participants from both East and West Europe made a plea to establish a European millennium partnership to develop long-term goals in order to start an international conservation and restoration process, involving nature conservationists, financial and economic experts, NGOs and land users.

The outcome of the conference will be presented to the European Union, the Council of Europe and the United Nations.

For further info: Rob Wolters, Executive Director, ECNC $T e l+31653691866$

E-mail:vanhal@ecnc.nl European Forest Institute News how necessary it is to consider carefully the arguments of third states and to develop convincing arguments for the time after IFF.

\section{European Forest Institute News}

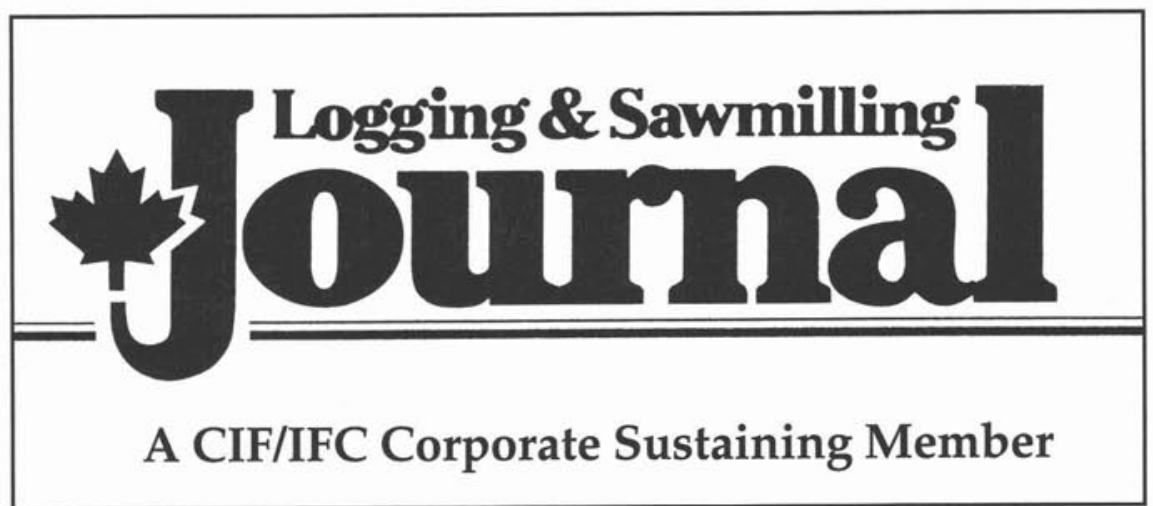




\section{FSC Certification May Violate WTO or Trade Laws}

My understanding is that forest management certification can be a trade barrier if, for purely technical reasons, it discriminates against certain producers. The most obvious example of where this may occur is in the case of small nonindustrial private forest owners. Due to their small size and inability to benefit from economies of scale, the relative costs of non-industrial owners gaining certification may be much higher than for larger industrial or public forest owners. Certification may discriminate against smaller owners on purely cost grounds and has nothing to do with the environmental performance of forest owners.

Also, despite all the claims to the contrary, ESC is still not truly "international" in the sense that it possesses an institutional framework encompassing a wide cross section of countries. FSC National Working Groups operate in around 20 countries around the world. The UK alone purchases timber from over 70 . The FSC has only five or six accredited certifiers. These are all western companies based either in Europe or the United
States. There are no FSC accredited certifying companies headquartered in Asia, Africa, South America, Russia, or even Canada. As a result, the costs of employing one of these accredited certifiers may well be higher in Pakistan say, than in the United States. This again could act as another form of discrimination.

If we take these arguments, and then look more closely at the extent to which certification is truly "voluntary," it soon becomes clear that FSC-type certification, if used inappropriately, could become a technical barrier to trade. If a large proportion of retailers, municipalities and other bodies require all their suppliers to undergo FSC certification, it soon becomes debateable as to whether suppliers have any real "choice." Indeed there are laws and regulations in most countries at the national level to prevent buying companies working together in this way. In the early 1990s, the WWF Buyers group in the UK required all its members to phase out non-FSC certified timber. However, following complaints from the UK's Timber Trade Federation, WWF were forced to amend their purchasing policy. Under UK and EC Trade law, companies are not allowed to co-ordinate purchasing policies favouring one particular form of certification over another as this constitutes a restrictive practice.

Getting back to the WTO, one of the few organisations that they do recognize as capable of certifying in a non-discriminatory way is ISO. This is because, unlike FSC, ISO has an institutional framework encompassing over 100 countries around the world. Many countries also have organisations capable of accrediting certifiers at national level (to ISO14001 for example). If FSC's institutional framework was much wider, if they seriously addressed the issue of small forest owners, and if they reduced their emphasis on "international accreditation" and instead worked through national-level accreditation bodies, many of these objections would disappear.

Rupert Oliver Editor, Tropical Timbers rjwoliver@email.msn.com

\section{Five African Countries Sign Major Pact}

The heads of five African countries have launched joint efforts to protect millions of hectares of biologically rich rainforests. At a summit in Yaounde, Cameroon, the leaders of Cameroon, Central African Republic, Congo (Brazzaville), Equatorial Guinea and Gabon pledged support for a series of "unprecedented" transboundary conservation projects. Among them are the designation of a new cross-border conservation area encompassing about 3.5 million hectares in Cameroon, Congo and Gabon; endorsement of an existing tri-national network of protected areas in Cameroon, Central African Republic and Congo; and creation of two new forest reserves in Cameroon. The summit also will endorse a campaign to save elephants and the rare western black rhinoceros in Cameroon.

The leaders will emphasize "an integrated approach to conservation" that protects forest while providing a livelihood for indigenous people and local communities who have traditionally lived in and around the forests.
A CIF/IFC Corporate
Sustaining Member themes at national, regional and global levels
European Forest Institute News

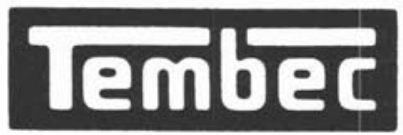

mulation: opportunities and cautions

Discussion papers 1-5

1. Mechanisms to identify, define and prioritise interdisciplinary forest research

Member
2 . Roles of the global and regional net3. Mechanisms for forestry research 4. Changing patterns of research funding: threat or opportunity for research on 5. Better access to information on forests information on forest" was the subject of lively discussion at the Gmunden fi.fif the EFI web site at : http.//wr efi.fi/files/icris.pdf. It is in PDF-format and requires Acrobat Reader to view it. 